\title{
Assessing Populism at Europe's Margins: Pervasive, Performative, Persistent
}

\section{Introduction to the Special Issue}

This special issue is a collection of articles whose authors explore different forms of populism in countries located beyond the Western core and therefore much less known to specialists in the field. The country-based case studies selected for this issue reflect diversity of populist forces in non-central polities in Europe. Each of them has a rich legacy of conflicts and controversies with major European powers, which serves as one of powerful sources of contemporary populist discourses, pushing many of them towards national reassertion and EU-skepticism.

The articles collected in this issue cover a variety of aspects of populist politics. Olga Lavrinenko speaks about 'technocratic populism' in Hungary and Czech Republic, Alexandra Yatsyk addresses 'biopolitical populism' in Poland, Ionut Chiruta explores memory-based populism in Romania, Michael Cole and Silas Marker engage ideologically explicit forms of populism, with strong nationalist and ethno-religious connotations, in (correspondingly) Georgia and Denmark, and Aliaksei Kazharski with Andrey Makarychev analyze performative populism in Slovakia and Estonia.

Lavrinenko's article on technocratic populism represents a particularly tough challenge to the habitual categorizations of populist narratives as an expressive and emotive opposition to post-political / administrative / managerial policy making. In her study she argues that populism has colonized the whole political spectrum and does not respect the traditional left-right or liberal conservative divides. This assumption is also shared by Kazharski and Makarychev who conclude that in Estonia and Slovakia populist methods of gaining public visibility in the media and performatively addressing 'the people' are spread all across the entire political spectrum. The inscription of populist approaches and narratives into administrative and managerial logics blurs the line between populism and technocracy. By the same token, a conceptualization of populism as an "economic project" grounded in a certain type of expertise and knowledge opens new avenues for-perhaps paradoxically_examining populism from a Foucault-inspired governmentality perspective. The variety of social, cultural and political spheres where populism exposes itself as a discourse 
shaper may lead us to presume that populism is a better fit to characterize what Michel Foucault dubbed capillary micro-policy practices, rather than regimes, parties or moreover countries. In other words, it is specific practices-such as memorialization of certain historical events, or marginalization of particular groups (immigrants or sexual minorities) — that make policy steps or measures populist. Of particular interest in this regard are 'populist parties' in governments, since they impel a hybrid form of politics: on the one hand, these parties stick with populist narratives, yet on the other hand their members are decision makers and have to show expertise in budgetary and financial issues, national defense and other spheres of governance.

This nuanced contextualization may help avoid undue overgeneralizations, and also may contribute to developing a post-foundational approach to populism, which interestingly resonates with analysis of populism as a phenomenon of post-socialist / post-communist transformations. In this sense, the plethora of populist discourses that most of Western polities had to discover and face only in the recent decade, was inscribed much earlier into mainstream politics in Eastern Europe and the South Caucasus. For example, Aliaksandr Lukashenka's rampant populism in Belarus seems to be a deeply post-Soviet phenomenon, as are the roots of the Georgian and Ukrainian versions of populism. Likewise, each case of mass-scale public mobilization against populist elites in Eastern Europe in recent years, 'colour revolutions' included, involved the activation of a performatively populist style.

This allows us to assume that populism is a transgressive political phenomenon that disregards ideological borders and often aims to bring together, under a singly performative style, groups and individuals with very diverse political preferences and sympathies. Both illiberal populism and populist resistance to it blend and synthesize various ideologies: there might be pro-capitalist and anti-capitalist constituencies among Vladimir Putin's (in Russia) or Volodymyr Zelensky's (in Ukraine) supporters, as well as the Maidan revolution of 20132014 or the anti-Lukashenka protests in Belarus in 2020 might embrace both cosmopolitan liberals and cultural nationalists.

One of the least researched areas in populism studies is transfer of policy practices / experiences from one polity to another. Michael Cole, for example, notes that Georgian right-wing populism has been to some extent inspired and ignited by the conservative wave in the West. Undoubtedly, Donald Trump or Marine Le Pen could serve as attractive reference figures for like-minded politicians beyond the Western core, although the scale and the scope of spill-over effects of this sort should not be overrated. Matteo Salvini's attempts to create a sort of "conservative international" so far didn't materialize, and National Rally's public contacts with their sympathizers in, for instance, Baltic states 
remain quite limited and sporadic. The same goes, by the way, for German right-wing populists from $A f D$ who internationally are much more in demand in Moscow than elsewhere in the post-Warsaw-Pact countries. Even less appealing to countries like Georgia, Poland, Estonia or Slovakia is the Russian version of what Alexandra Yatsyk terms 'biopolitical conservatism'.

The Covid-19 emergency has undoubtedly opened a new space for populist politics, and elucidated the ability of illiberal populism to make direct connections between different events - such as the refugee crisis and the outburst of the pandemic, which is illustrated in Marker's article in this issue. These chains of discursively constructed equivalences may well explain the thickening of populist agendas through their saturation with diverse meanings and references to multiple events. Yet in the meantime the global 'state of exception' in 2020 has further fragmented the field of populist politics into a number of segments with divergent worldviews, from Covid-deniers / Covid-dissidents to authoritarian populists like Viktor Orban who used the emergency for ruling by decree. This diversity of populist practices complicates academic categorization of the concept, yet duly reflects the broad spectrum of political developments that trigger dissimilar and even conflicting populist reactions.

The multiple dimensions of populism as ideology, performance, psychology and governance require attention across the spaces in which it is present. This special issue expands the analysis of populism into spaces that have been comparatively unexamined in the broad field of populism studies. Such expansion helps us reflect on and critically examine our understanding of populism as a phenomenon and as a political project. We are pleased to have the opportunity to bring these perspectives to the continuing analysis of populism around the world.

Andrey Makarychev and Lane Crothers 